Louisiana State University

LSU Digital Commons

$9-1-2007$

\title{
Description, life history, and parasitism of a new species of Delphacid Planthopper (Hemiptera: Fulgoroidea)
}

James T. Cronin

Louisiana State University

Stephen W. Wilson

University of Central Missouri

Follow this and additional works at: https://digitalcommons.Isu.edu/biosci_pubs

\section{Recommended Citation}

Cronin, J., \& Wilson, S. (2007). Description, life history, and parasitism of a new species of Delphacid Planthopper (Hemiptera: Fulgoroidea). Annals of the Entomological Society of America, 100 (5), 640-648. https://doi.org/10.1603/0013-8746(2007)100[640:DLHAPO]2.0.C0;2 


\title{
Description, Life History, and Parasitism of a New Species of Delphacid Planthopper (Hemiptera: Fulgoroidea)
}

\author{
JAMES T. CRONIN ${ }^{1}$ AND STEPHEN W. WILSON ${ }^{2}$
}

Ann. Entomol. Soc. Am. 100(5): 640-648 (2007)

\begin{abstract}
Delphacodes scolochloa Cronin \& Wilson (Hemiptera: Fulgoroidea) is a newly discovered delphacid planthopper that feeds and oviposits exclusively on the stems of sprangletop, Scolochloa festucacea (Willd.) Link (Poaceae: Pooidae), in the prairie pothole region of northeastern North Dakota. D. scolochloa is bivoltine. It is also wing dimorphic, but populations are composed predominantly of flightless brachypters. Macropters incur a substantial cost in terms of reduced longevity and fecundity relative to brachypters. The parasitoid complex attacking $D$. scolochloa consists of two egg parasitoids, Anagrus nigriventris Girault and Anagrus columbi Perkins (Hymenoptera: Mymaridae), and one undescribed dryinid. The proportion of eggs parasitized averages $21 \%$, and egg parasitization is density independent.
\end{abstract}

KEY WORDS Anagrus nigriventris, egg parasitoid, planthopper, prairie potholes, Scolochloa festucacea

Grass-feeding delphacids have been the subject of extensive ecological research, primarily because several species are vectors of pathogens of economically important grasses (Wilson 2005). In North American grasslands and salt marshes, researchers have focused on faunal surveys (e.g., Hendrickson, 1930, Wilson et al. 1993, Hamilton 2002), systematics and morphology (e.g., Wilson 1982, Miller and Wilson 1999), life histories (e.g., Holder and Wilson 1992), and mating behavior (e.g., Heady and Denno 1991, Heady and Wilson 1990). Delphacids also have been used to address a broad range of ecological questions regarding plant-herbivore interactions (e.g., Tallamy and Denno 1979, Denno 1983, Denno et al. 1986, Wilson et al. 1994), life history theory (e.g., Denno and Dingle 1981, Denno and McCloud 1985, Huberty and Denno 2006), population dynamics (e.g., Denno 1983, Strong 1989, Reeve et al. 1994), interspecific competition (Denno and Roderick 1992, Denno et al. 2000, Ferrenberg and Denno 2003), predator-prey interactions (Döbel and Denno 1994, Cronin et al. 2004, Fagan and Denno 2004), host-parasitoid interactions (e.g., Stiling and Strong 1982; Cronin and Strong 1990, 1993, 1999; Cronin 2003b), food web structure (e.g., Denno et al. 2002, Finke and Denno 2003, Gratton and Denno 2003), dispersal and metapopulation dynamics (Cronin 2003a, Haynes and Cronin 2006), and landscape ecology (Haynes and Cronin 2003, 2006; Cronin and Haynes 2004).

Some grass-feeding delphacids are ecologically similar to pests such as the brown planthopper, Nilaparvata lugens (Stål.), a serious pest of rice, Oryza sativa

\footnotetext{
${ }^{1}$ Corresponding author: Department of Biological Sciences, Louisiana State University, Baton Rouge, LA 70803 (e-mail: jcronin@lsu.edu).

${ }^{2}$ Department of Biology, University of Central Missouri, Warrensburg, MO 64093.
}

L. (Kiritani 1979, Wilson and Claridge 1985). These delphacids also serve as hosts to mymarid, strepsipteran, and dryinid parasitoids, an assemblage of parasitoids very comparable to that found for many planthopper pest species (e.g., Ôtake 1970, Bentur et al. 1982, Fowler et al. 1991). The study of host-parasitoid interactions in species of grassland delphacids may provide insight or potential biocontrol agents for the suppression of related pest species.

Here, we describe a new species of delphacid planthopper and provide data on its biology, host range, rate of macroptery, and population dynamics. We also identify the parasitoid species that attack the planthopper, quantify rates of parasitism, and test whether the proportion parasitized among host plant patches depends on host density.

\section{Materials and Methods}

Study Location and Host Plant. Collection of specimens and census of planthopper and parasitoid populations occurred in the prairie pothole region of northeastern North Dakota (Petersburg, Nelson County; $48.02097^{\circ} \mathrm{N}, 98.12230^{\circ} \mathrm{W}$ ). This formerly glaciated area is characterized by numerous seasonal and permanent ponds (van der Valk 1989), and it is an important breeding habitat for waterfowl (Batt et al. 1989). Among the wetland plants bordering these ponds is the native sprangletop or common river grass, Scolochloa festucacea (Willd.) Link (Poaceae: Pooidae). Sprangletop is circumpolar in distribution and in North America ranges from northern Iowa and Nebraska to southcentral Canada and west to Oregon (Gould 1968, Clayton and Renvoize 1986). Ecologically, it is an emergent hydrophyte, and it is found where water levels fluctuate from 0 to $150 \mathrm{~cm}$ above 

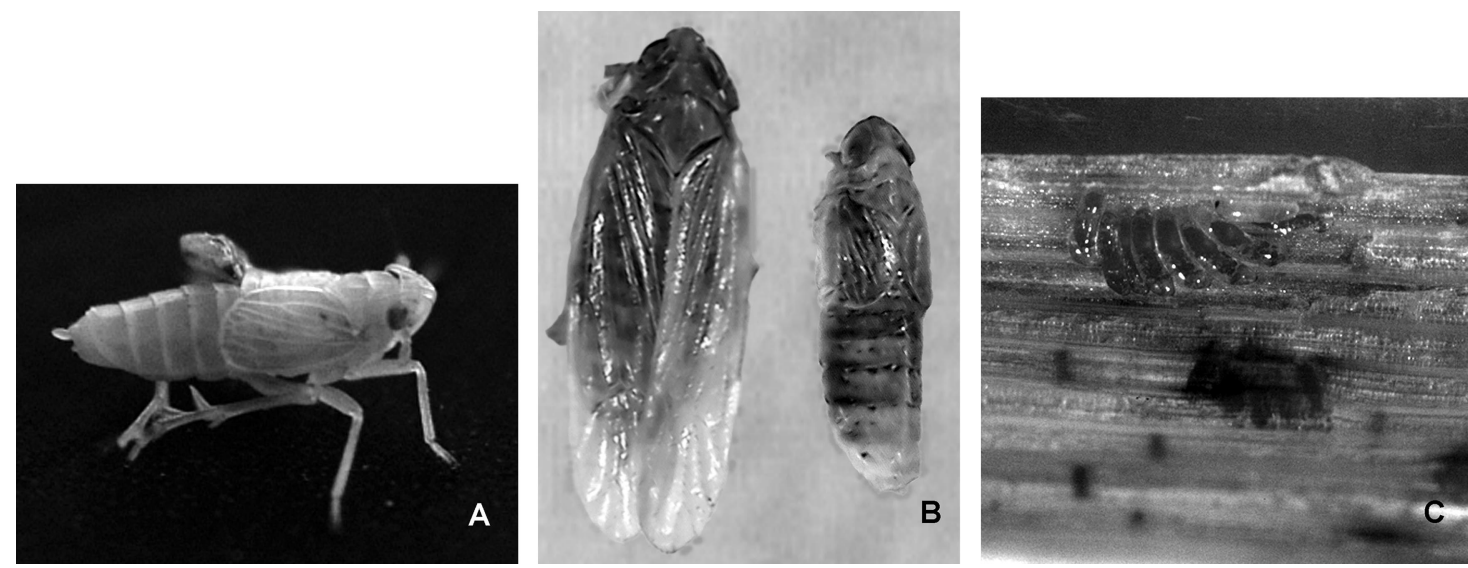

Fig. 1. D. scolochloa. (A) Adult brachypterous female with dryinid parasitoid sac. (B) Macropterous and brachypterous females. (C) Egg clusters on S. festucacea stems that have by parasitized by Anagrus spp. (plant epidermis has been removed to expose eggs in the upper egg cluster).

the soil surface (Sculthorpe 1967). Sprangletop often forms pure stands several meters deep along the pond margins and as small clonal patches further in open shallow water (Smith 1973; J.T.C., unpublished data).

Population Census. Three semipermanent ponds, broadly bordered by sprangletop, were used in this study (Ponds 100, 109, and N29-1). The ponds were 1-3 ha in size and were separated from each other by $1.8-5.6 \mathrm{~km}$. Shortly after spring thaw, mid-May 1998 , the sprangletop bordering each pond was sampled with a sweepnet. Three sets of 10 sweeps each were conducted per pond. Sweep samples were transported on ice to the laboratory, and planthoppers were inspected to determine stage (nymph or adult), sex, wing morph (brachypters versus macropters; Fig. 1, A and $B$ ), and presence of parasitoids protruding from between the abdominal segments (dryinid larval sac or strepsipteran cephalothorax) (Fig. 1A). Surveys were conducted at 2-wk intervals until the end of the summer when sprangletop had completely senesced (early September). The survey was continued each season for $3 \mathrm{yr}$.

For each planthopper generation, after adults had become scarce, we conducted a census of planthopper eggs. Twenty-five sprangletop stems with planthopper eggs were haphazardly collected from each pond. Stems were left to incubate for $3 \mathrm{~d}$ at room temperature (stem bases were submerged in water) to ensure that recently parasitized hosts could be identified. Stems were subsequently dissected under a stereoscopic dissecting microscope $(10 \times)$ to expose planthopper eggs inserted just beneath the stem epidermis (Fig. 1C). Planthopper eggs were identified as either healthy (developing white embryos or as cast chorions, indicating successful emergence), parasitized (red immatures, or host chorions with circular exit holes, indicating successful emergence), or dead (deflated or brown eggs). A subset of planthopper nymphs and adults and egg parasitoids were preserved in $70 \%$ ethanol for later identification of species.
Planthopper Taxonomy. The specimens collected from S. festucacea represent a new species, and they are described below. Descriptions are based on nine males and 34 females. Using an ocular micrometer, body length was measured from the apex of the vertex to posterior aspect of the abdomen. Thoracic length was measured along the midline from the anterior aspect of the pronotum to the posterior aspect of the mesonotal scutellum as the metanotum is obscured by the forewings. To describe and illustrate the male and female genitalia, the abdomen was removed and placed in a 10\% KOH solution overnight, then washed in distilled water; genitalia were stored in genitalia capsules filled with glycerol (Wilson 2005). The terminology used in describing the female genitalia follows Heady and Wilson (1990).

Host Range of D. scolochloa. To ascertain the host range of the planthopper, we caged planthopper adults onto potted stems of the 11 dominant plant species at our field sites. These plant species were the grasses spangletop, switch grass (Panicum virgatum L.), prairie cordgrass (Spartina pectinata Link), and smooth brome (Bromus inermis Leyss.); common reed [Phragmites australis (Cav.) Trin]; sedges (Carex sp.); rushes (Scirpus sp.); cattails (Typha spp.); Canada goldenrod (Solidago canadensis L.); smart weed (Polygonum sp.); and thistle (Circium sp.). Two common grass crops, corn (Zea mays L.) and wheat (Triticum aestivum L.), also were included in this study. Young, nonflowering shoots of the noncrop plants were excavated from the field in early June 1999 and potted in Pro-mix BX soil (20-cm-diameter pots). Corn was grown from seed (Burpee Seed Co., Warminster, PA, Early Choice Hybrid SE variety), and wheat was obtained as seedlings from a local farmer. Both crop plants were grown in 20-cm pots by using Pro-Mix BX. Clear Mylar sheeting, formed into tubes, were inserted over the plants. The tops of the cages were constructed of mosquito netting hot-glued to the Mylar. Twenty-five recently eclosed adult planthoppers were added to each cage, and there were three caged plants per plant spe- 
cies. Cages were inspected daily for live planthoppers and evidence of feeding (excretion of honeydew). After all planthoppers had died, the plants were carefully inspected for planthopper eggs.

Longevity and Fecundity of Wing-Dimorphic Females. Several hundred late instars of D. scolochloa, collected from the field in late May 1998, were placed on potted sprangletop plants that were enclosed with a Mylar cage (see above). Each day, newly eclosed adults were removed and sorted by sex and wing type. Adults were quickly transferred to stem cages in groups of either six brachypterous or six macropterous females. In addition, two macropterous males were added to each cage ( $>99 \%$ of males are macropterous in this species). The stem cage was constructed of a 10 -cm-long by $2.5-\mathrm{cm}$-diameter acetate tube. Highdensity foam sealed the ends of the tube around the stem and kept the stem positioned in the center of the tube. The experiment consisted of 10 replicate cages per wing type.

Every day until all planthoppers had died, the cages were inspected, and the number of live females was counted. Planthoppers were gently aspirated and transferred to new stem cages at 2-day intervals. This procedure ensured that planthoppers had high-quality host material for feeding and oviposition. Also, males were maintained at two individuals per cage throughout the experiment to ensure that females were not sperm limited.

Differences in survival curves between female brachypters and macropters were analyzed with a Wilcoxon's rank test (Pyke and Thompson 1986). We also tested for differences in median and maximum life spans (days to 50 and $100 \%$ mortality per replicate, respectively) and fecundity by using two-sample $t$ tests. We used two fecundity metrics, mean daily fecundity (=total eggs laid/summation of females alive to start each day) and mean lifetime fecundity (=total eggs laid/initial number of females) per replicate cage. All tests were performed in SYSTAT 11 (Systat Software, Inc., Point Richmond, CA).

Parasitism and Host Density. Based on stem collections made during the census, we examined the relationship between host density and proportion parasitized among stems. Spatial density dependence was examined using separate least-squares regression models for each site $(n=3)$ and planthopper generation $(n=6)$ for a total of 18 tests. Eggs per stem was $\ln$ transformed, and proportion parasitized was arcsine square root transformed to achieve normality and homogeneity of variances (Sokal and Rohlf 1995). We report the fraction of tests that had a positive or negative slope and how many were statistically significant $(P<0.05)$.

\section{Results}

\section{Delphacodes scolochloa Cronin \& Wilson, New Species}

Salient Features. Total length: male $1.92 \pm 0.095$ $\mathrm{mm}$, female $3.04 \pm 0.227 \mathrm{~mm}$; thoracic length: male
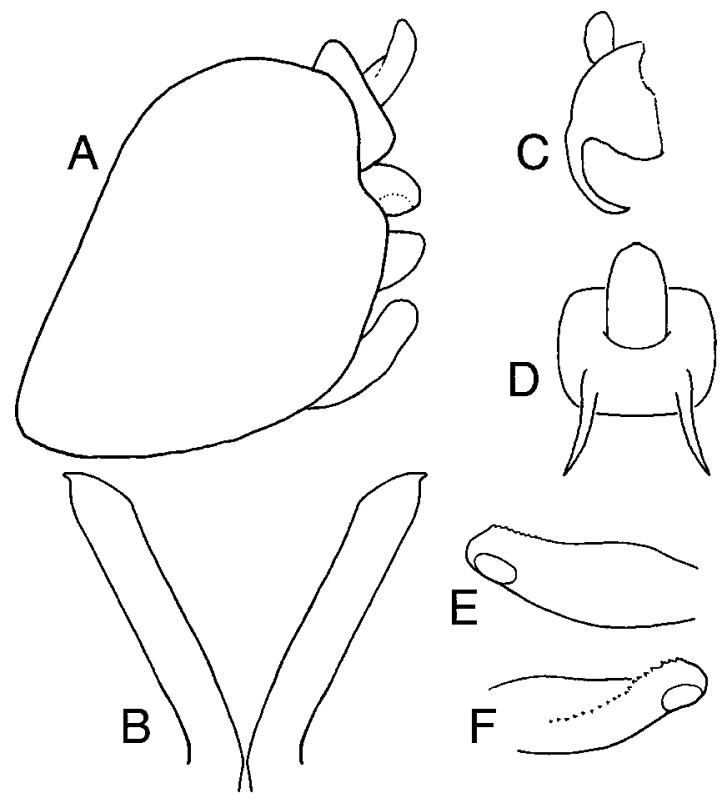

Fig. 2. D. scolochloa male external genitalia. (A) Pygofer, anal tube, aedeagus, and style, left lateral view. (B) Styles, caudal view. (C) Anal tube, right lateral view. (D) Anal tube, caudal view. (E) Aedeagus, right lateral view. (F) Aedeagus, left lateral view.

$0.60 \pm 0.022 \mathrm{~mm}$, female $0.70 \pm 0.057 \mathrm{~mm} ; n=7$ males, 32 females.

Body pale, yellow/light brown to dark brown with fuscous markings. Vertex subquadrate with prominent darker lateral carina, concolorous $\mathrm{V}$-shaped posteriorly directed carina near middle; in lateral view, vertex curving onto frons. Frons narrow, approximately twice as long as wide, bordered by darker subparallel lateral carinae, with concolorous weak median longitudinal carina. Clypeus with prominent partial median longitudinal carina. Antennal scape subcylindrical, pedicel length $\approx 2.5 \times$ that of scape.

Pronotum with lateral carinae curving posterolaterally, paralleling curvature of compound eyes; with prominent median longitudinal carina. Mesonotum length about twice that of pronotum; with straight, posterolaterally directed lateral carinae and a median longitudinal carina. Forewings translucent pale brown, veins concolorous bearing short setae; macropters with forewing narrow, broadly rounded apically and extending well beyond apex of abdomen; brachypters with forewing subquadrate extending to abdominal tergite 6 . Legs with apices of tarsi fuscous; metatibial spur subequal in length to that of basal metatarsomere, with row of very small black tipped teeth on posterolateral aspect; basal metatarosmere $\approx 3 \times$ length of middle metatarsomere, which is subequal in length to that of terminal metatarsomere.

Abdominal tergite 3 fuscous.

Male genitalia (Fig. 2). Pygofer pale brown with black marking on ventrocaudal aspect; in lateral view, subquadrate, with caudal margin in dorsal one third gently concave; diaphragm armature shining black, 


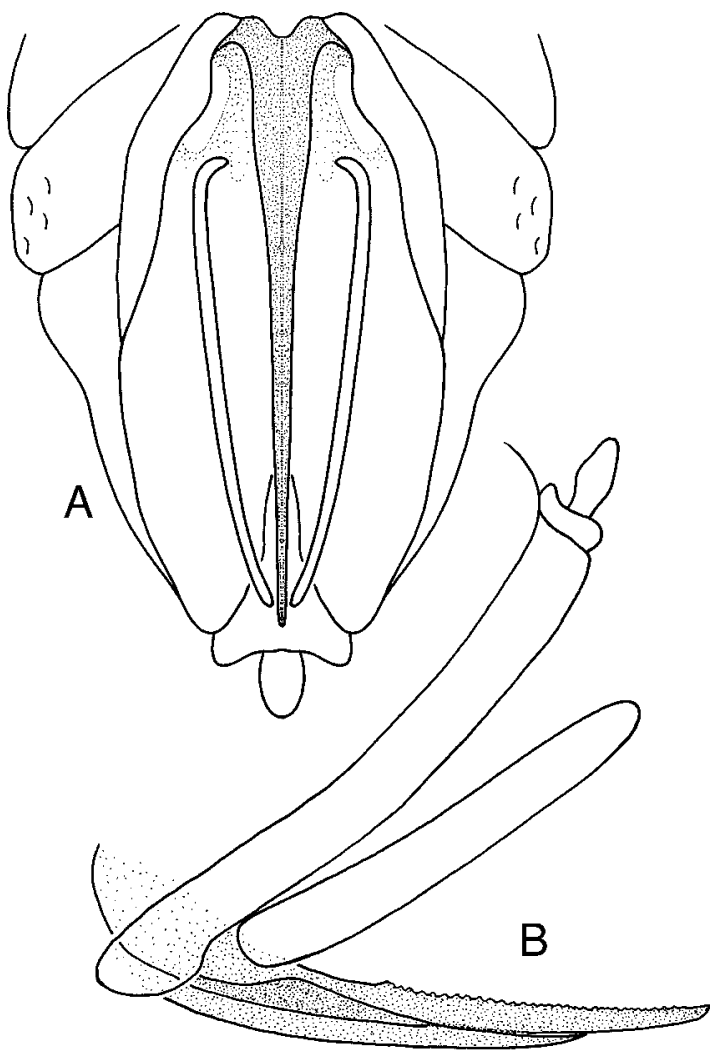

Fig. 3. D. scolochloa female external genitalia. (A) Apical portion of abdomen, ventral view. (B) Apical portion of abdomen, left lateral view.

extending posteriorly as a bulbous process. Anal tube, in lateral view, with a pair of broadly separated, curved, ventroanteriorly directed spinose processes originating on the ventrocaudal aspect of the tube. Styles, fuscous; in caudal view, curved dorsolaterally at base then elongate, subparallel narrowing abruptly to a small pointed apex. Aedeagus subcylindrical, apex broadly rounded, gonopore on ventral aspect near apex; with curving row of $\approx 20$ teeth extending from dorsal aspect anterolaterally on left side to near middle.

Female genitalia (Fig. 3). Tergite 9, in ventral view, elongate, each side broad with length $\approx 3 \times$ width, apex rounded. Anal tube subcylindrical. Valvifers of segment 8 each covering tergite 9 anterolaterally; elongate, slender, broadly convex on lateral aspect, sinuate on median aspect. Lateral gonapophyses of segment 9 elongate, spatulate posteriorly. In lateral view, median gonapophyses of segment 9 sabershaped, with $\approx 30$ prominent small teeth on dorsal margin in distal one half. Gonapophyses of segment 8 adhering tightly to median gonopophyses of segment 9; slender, acute apically.

Types. HOLOTYPE: male, North Dakota, Nelson Co., Petersburg, $48.00206^{\circ}$ N, $97.97222^{\circ}$ W, 4 June 1998 , ex. Scolochloa festucacea, coll. J. Cronin. ALLOTYPE: female, same data (primary types deposited in the

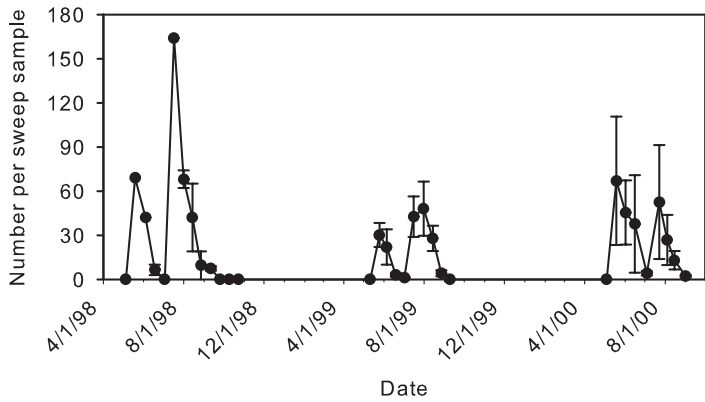

Fig. 4. Mean \pm SE number of adult D. scolochloa (sum of three sets of sweeps) among three prairie potholes based on biweekly samples for 3 yr (1998-2000).

Snow Museum, University of Kansas). PARATYPES: 8 males, 33 females, same data ( 2 males, 4 females deposited in the Snow Museum, the remainder deposited in SWW Collection).

Distribution. This species is known from S. festucacea from eastern North Dakota, but it is likely to be more widely distributed in North America because its host plant is found along the margins of lakes and prairie potholes from central Canada south to Iowa and west to Oregon.

Etymology. D. scolochloa is named for the genus of its host plant.

Life History. D. scolochloa overwinters as mid-instar nymphs concealed beneath the senescent leaf sheaths that are loosely attached to the sprangletop stems. In early May, corresponding with the emergence of new sprangletop shoots, the nymphs emerge from their winter refuge and begin to feed. Planthoppers extract phloem from the stems, typically feeding above the water line but below the lowest unfurled leaf. However, on occasion, some feeding does take place at the base and abaxial surface of leaves. Toward the end of May, adults achieve maximal density (Fig. 4). Females lay eggs in clusters just beneath the stem epidermis (Fig. 1C) and in complete overlap with their feeding sites. Emergence of nymphs follows egg laying by $\approx 2$ wk. Planthoppers have two nonoverlapping generations per summer; peak adult densities for the second generation occur in the middle of July (Fig. 4). By the latter half of August, no adults are present in the population.

Feeding and oviposition on the stems of sprangletop caused necrotic lesions to form and be visible within 2 wk. The damage was especially evident after the outbreak of planthoppers in July 1998 (Fig. 4). However, heavy stem damage at this time did not translate into a reduction in plant height or flowering frequency at the end of the growing season. Based on a sample of 100 heavily scarred and 100 unscarred stems at site 100 , heights differed by only $3 \%$ (scarred, $1.22 \pm$ $0.04 \mathrm{~m}$ and unscarred, $1.26 \pm 0.05 \mathrm{~m} ; t_{198}=0.62, P=$ $0.27)$. Flowering rates were actually slightly higher for the damaged plants (scarred, 38\%; unscarred, 33\%).

Based on census data, the percentage of males over all $3 \mathrm{yr}$ was $34 \pm 5 \%$ (mean $\pm \mathrm{SE} ; n=3$ sites). One hundred percent of the collected males were mac- 


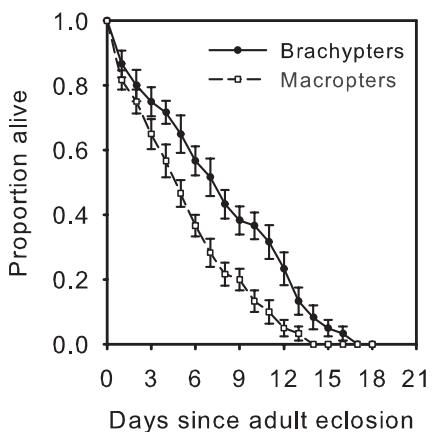

Fig. 5. Survivorship curves for brachypterous and macropterous female $D$. scolochloa. Mean $\pm \mathrm{SE}$ proportion alive per cage per day $(n=10)$.

ropterous (forewings extending beyond the abdomen). In contrast, only $9.1 \pm 5.1 \%$ of the females were macropterous. Brachypterous D. scolochloa have wings that are too small to allow sustained flight. Individuals were observed to weakly "flutter" their forewings between stems.

D. scolochloa seems to be monophagous in the prairie pothole region of northeastern North Dakota. Of the 13 species of plants on which this planthopper was caged, feeding, as indicated by the presence of honeydew, was only evident on sprangletop. Caged planthoppers on sprangletop had a median adult life span of $6.6 \pm 1.8 \mathrm{~d}$, whereas planthoppers on the remaining 12 species had a median life span of $<1$ d. Finally, all three caged sprangletop plants were heavily infested with planthopper eggs, but none of the other plant species had eggs.

Brachypterous and macropterous females differed significantly in survivorship curves (Wilcoxon test: $Z=3.52, P<0.001$ ) (Fig. 5). Median (number of days to $50 \%$ mortality) and maximum (days to $100 \%$ mortality) adult life span was 23 and $21 \%$ higher, respectively, for brachypters than macropters (Fig. 6A). The difference between wing morphs was highly significant for maximum life span $\left(t_{18}=3.37, P=0.003\right)$, but only marginally significant for median life span $\left(t_{18}=\right.$ $1.91, P=0.072$ ). Daily oviposition rates (eggs laid per alive female per day per replicate) were $21 \%$ higher for brachypters than macropters (Fig. 6B), but this difference was not significant $\left(t_{18}=1.57, P=0.13\right)$. In contrast, brachypters had a substantial advantage $(46 \%)$ over macropters in terms of lifetime fecundity (total eggs laid per female per replicate) $\left(t_{18}=4.31\right.$, $P=0.004)$.

Parasitoids. Over the course of six planthopper generations, an average of $21.2 \pm 4.6 \%$ of the planthopper eggs was parasitized. Two species of parasitoids were reared from these collections, Anagrus nigriventris $\mathrm{Gi}-$ rault and Anagrus columbi Perkins (Hymenoptera: Mymaridae; Chiappini et al. 1996, Triapitsyn 1997). Voucher specimens can be found at the Department of Entomology, University of California, Riverside. Based on a subsample of parasitoids spanning all sites and years $(n=64), 92 \%$ of the individuals were identified as A. nigriventris.

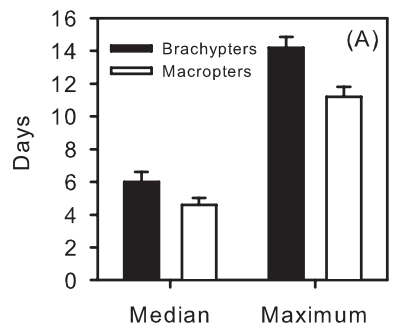

Adult longevity metrics

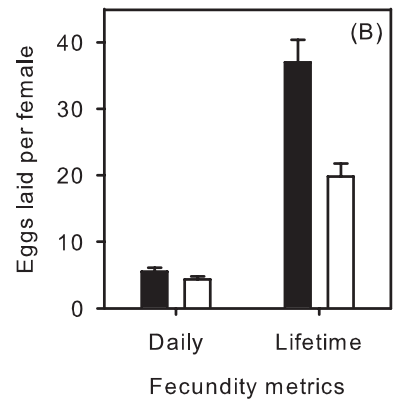

Fig. 6. Longevity and fecundity of newly eclosed $D$. scolochloa females. (A) Mean $\pm \mathrm{SE}$ days to $50 \%$ (median longevity) and $100 \%$ (maximum longevity) survivorship of planthoppers. (B) Mean \pm SE eggs laid per female per day given that it survived the day (daily fecundity) and eggs produced over the life span of the females (lifetime fecundity).

At the spatial scale of individual sprangletop stems, we detected no evidence that parasitism was density dependent. None of the 18 regression analyses was statistically significant. Moreover, there was no trend with regard to the slopes of the density-parasitism relationship: exactly one half of the tests had a positive or negative slope.

Based on the 3 -yr census, $2.7 \%$ of the late instars and $1.5 \%$ of adults exhibited a sac protruding from the abdominal segments. Parasitized specimens were collected and placed in small stem cages on sprangletop. For some individuals, a larva emerged from the sac and spun a cocoon at the bottom of the cage. Wingless female dryinids emerged from these cocoons.

\section{Discussion}

Diagnostic morphological characters that serve to separate D. scolochloa from similar delphacids include the narrow, parallel-sided frons, the curved pronotal lateral carinae, and the distinctive male genitalia. This species shares some features with members of the genus Nothodelphax such as its small but relatively robust body form, small pygofer, elongate paired anal tube spines, and flattened simple genital styles. It differs from Nothodelphax in its lighter coloration (most Nothodelphax are black), slightly larger body size, broader pygofer in caudal aspect, and larger diaphragm opening, longer styles, and lack of a distinctive flange along the length of the aedeagus. Due to the difficulty in placing this species, we assigned it to the 
genus Delphacodes (sensu lato), recognizing that its generic placement will be reassigned upon revision of the North American Delphacodes.

This is the first species of delphacid planthopper known to feed on S. festucacea, which is very patchy in its distribution, limited to the margins of ponds, drainages, and wet depressions. In the prairie pothole region of North Dakota, farmland is the primary intervening habitat. In the habitat in which this study was conducted, prairie cordgrass, the host for a similar delphacid, Prokelisia crocea (Van Duzee), can be found growing adjacent to sprangletop along pond margins. D. scolochloa has a very similar biology, life history, and parasitoid fauna to that of the well-studied members of the genus Prokelisia (P. marginata, P. dolus, and P. crocea). All four species are found in wetlands, and they are monophagous on their host plants (Denno and Grissell 1979, Denno et al. 1987, Holder and Wilson 1992, Cronin 2003a). Nymphs are the overwintering stage, with individuals seeking refuge in the leaf litter or rolled dead leaves or sheaths of standing vegetation (Denno 1977, Cronin 2003a). Eggs are laid in the subepidermis, but $D$. scolochloa is unique in that its eggs are laid predominantly in the stems of its host. For all species, feeding and oviposition sites completely overlap.

As with many species of delphacids, D. scolochloa is wing-dimorphic (Denno et al. 1991). Females are predominantly brachypterous, whereas males are almost entirely macropterous. $P$. dolus females are also predominantly brachypterous, but the opposite pattern is observed for P. marginata and P. crocea females. Mark-recapture experiments with macropterous and brachypterous $D$. scolochloa confirm the importance of long wings to both within- and among-patch movements (J.T.C., unpublished data). Not only was the rate of spread within a sprangletop patch significantly higher for macropterous females, but colonization of isolated patches located $>5 \mathrm{~m}$ away was predominantly by macropterous females.

For D. scolochloa, there is a significant trade-off between dispersal ability and fitness. Adult maximum life span and lifetime fecundity of macropters were reduced by 21 and 46\%, respectively, in comparison with brachypterous individuals. Such trade-offs are also evident in P. marginata and P. dolus (Denno et al. 1989) and with numerous other wing-dimorphic species (e.g., Roff 1984, 1986; Zera 1984). Because of the fitness costs associated with macroptery, evolutionary theory suggests that insects should exhibit reduced dispersal in persistent as compared with temporary habitats (Roff 1990, Denno et al. 1991). Moreover, Denno et al. (1996) found a significant negative relationship between dispersal capacity (macroptery rates) and habitat persistence for P. dolus and P. marginata (for reviews of other insects, see Roff 1990 and Denno et al. 1996). A priori, we therefore might expect that $P$. crocea and D. scolochloa exist in relatively ephemeral and permanent habitats, respectively, in the Great Plains. This prediction remains to be tested.

Despite the dominance of $D$. scolochloa as an herbivore of sprangletop, we found no evidence that it had an effect on plant performance (e.g., stem height and flowering frequency), even in high-density situations. However, it would be premature to conclude that sprangletop does not suffer damage from $D$. scolochloa. Long-term or cumulative effects of herbivory and impact on seedlings have not been addressed. Studies with $P$. dolus and $P$. marginata have revealed significant impacts on host plant fitness, especially in areas where the host-herbivore interaction is relatively recent (e.g., < $100 \mathrm{yr}$; Olmstead et al. 1997; Daehler and Strong 1995, 1997; Garcia-Rossi et al. 2003). Of course, ecologically similar species of planthoppers, such as the pests Delphacodes kuscheli Fennah and N. lugens, have a tremendous impact on their hosts (Kiritani 1979, Brentassi and Maldonado 2002, March et al. 2002).

As is typical for delphacid planthoppers, D. scolochloa is host to egg parasitoids in the genus Anagrus. A. nigriventris, the dominant egg parasitoid (accounting for an estimated $92 \%$ of the parasitized hosts), is a common and widespread North American species (Chiappini et al. 1996). A. columbi, was known from only a few specimens and localities (Chiappini et al. 1996), but recently it has been discovered in $P$. crocea eggs in northeastern North Dakota (Cronin 2003b). P. crocea and D. scolochloa share both Anagrus parasitoids at our field sites in Petersburg, Co., ND, and there is evidence that apparent competition occurs between these two planthopper species (Cronin 2007). Apparent competition is a type of indirect interaction in which one species has a negative effect on another species mediated through a shared natural enemy (Holt 1977; Holt and Lawton 1993, 1994). Interestingly, $50 \mathrm{~km}$ to the east, where $S$. festucacea is uncommon, $P$. crocea is only parasitized by A. columbi (Cronin 2003b). Members of the genus Anagrus are important natural enemies of pests in a variety of agricultural crops, including rice (Ôtake 1970), corn (Liljestrom and Virla 2004), sugarcane (Saccharum officinarum L) (Metcalfe 1972) (Poaceae), grapes (Vitis spp.; Vitaceae) (Settle and Wilson 1990, English-Loeb et al. 2003), sugar beets (Beta vulgaris L.; Chenopodiaceae) (Meyerdirk and Moratorio 1987), and apples (Malus domestica Borkh.; Rosaceae) (Teulon and Penman 1986).

Parasitism of $D$. scolochloa eggs was modest, averaging only $21 \%$, and there was no evidence of spatial density-dependent parasitism at the scale of individual stems. The absence of density-dependent parasitism contrasts with the findings for D. kuscheli (Liljestrom and Virla 2004), but it is typical of the pattern for many planthoppers and leafhoppers (Cronin and Strong 1990, 1994; Cronin 2003a).

Nymphal-adult parasitism by dryinids is rare, averaging only $\approx 2 \%$. Stiling and Strong (1982), Stiling et al. (1991), and Cronin (2003b) found similarly low levels of parasitism for Prokelisia spp. With regard to parasitoid assemblages, the two prairie planthoppers $(D$. scolochloa and $P$. crocea) have less diversity than the coastal Prokelisia in that they lack strepsipteran parasitoids. Along the gulf coast of Florida, up to $20 \%$ of the 
nymphs are parasitized by Elenchus koebelei Pierce (Strepsiptera: Elenchidae) (Stiling et al. 1991).

In summary, we have identified a new species of delphacid planthopper in North America whose biology, life history, and natural enemy complex are similar to other well-studied nonpest grass-feeding delphacids. It exists in a highly fragmented wetland environment, feeds on a novel host plant, and is predominantly brachypterous. This species also serves as a reservoir for two Anagrus parasitoids that could potentially be useful in biological control programs. Owing to an extraordinary base of ecological research on grass-feeding delphacids, we have the opportunity to examine how differences in key life history parameters or habitat structure influence various ecological processes. For example, we plan to conduct a comparative analysis of the metapopulation dynamics of $P$. crocea and D. scolochloa that occupy the same habitat (prairie potholes) but that differ fundamentally in dispersal ability (J.T.C., unpublished data). We also can explore differences in population dynamics between species that live in highly fragmented $(P$. crocea and $D$. scolochloa) versus relatively large continuous habitats ( $P$. dolus and P. marginata) and the consequences of shared parasitoids between sympatrically occurring planthopper species.

\section{Acknowledgments}

The following people assisted with the fieldwork: R. Beasler, J. Geber, T. Hanel, S. Jorde, M. Szymanski, A. Widdell, and M. Williams. K. Thompson (U.S. Fisheries and Wildlife Service) granted us permission to work at sites 100 and 109 (Waterfowl Production Areas), and D. and J. Ralston graciously allowed us to conduct research on personal property (site N29-1). Special thanks to S. V. Triapitsyn for identifying and providing mounted specimens of Anagrus species. This work was supported by The University of North Dakota, ND EPSCoR (EPS-9874802), The University of North Dakota Alumni Foundation, Louisiana State University, and National Science Foundation grants DEB-9973789, DEB-0211359, and DEB-0515764.

\section{References Cited}

Batt, B. D., M. G. Anderson, C. D. Anderson, and F. D. Caswell. 1989. The use of prairie potholes by North American ducks, pp. 204-227. In A. van der Valk [ed.], Northern prairie wetlands. Iowa State University Press, Ames, IA.

Bentur, J. S., M. Sain, and M. B. Kalode. 1982. Studies on egg and nymphal parasites of rice planthoppers, Nilaparvata lugens (Stål) and Sogatella furcifera (Horvath). Proc. Indiana Acad. Sci. Anim. Sci. 91: 165-176.

Brentassi, M. E., and S. Maldonado. 2002. Penetration and feeding damage produced by Delphacodes kuscheli on maize and barley leaves (Hemiptera, Fulgoromorpha, Delphacidae). Ann. Soc. Entomol. Fr. 38: 271-276.

Chiappini, E., S. V. Triapitsyn, and A. Donev. 1996. Key to the Holarctic species of Anagrus Haliday (Hymenoptera: Mymaridae) with a review of the Nearctic and Palaearctic (other than European) species and descriptions of new taxa. J. Nat. Hist. 30: 551-595.
Clayton, W. D., and S. A. Renvoize. 1986. Genera Graminum: grasses of the world. Her Majesty's Stationary Office, London, United Kingdom.

Cronin, J. T. 2003a. Movement and spatial population structure of a prairie planthopper. Ecology 84: 1179-1188.

Cronin, J. T. 2003b. Patch structure, oviposition behavior, and the distribution of parasitism risk. Ecol. Monogr. 73: 283-300.

Cronin, J. T. 2007. Shared parasitoids in a metacommunity: indirect interactions inhibit herbivore membership in local communities. Ecol. Monogr. (in press).

Cronin, J. T., and K. J. Haynes. 2004. An invasive plant promotes unstable host-parasitoid patch dynamics. Ecology 85: 2772-2782.

Cronin, J. T., and D. R. Strong. 1990. Density-independent parasitism among host patches by Anagrus delicatis: experimental manipulations of hosts. J. Anim. Ecol. 59: $1019-1026$.

Cronin, J. T., and D. R. Strong. 1993. Substantially submaximal oviposition rates by a mymarid egg parasitoid in the laboratory and field. Ecology 74: 1813-1825.

Cronin, J. T., and D. R. Strong. 1994. Parasitoid interactions and their contribution to the stabilization of Auchenorrhyncha populations, pp. 400-428. In R. F. Denno and T. J. Perfect [eds. ], Planthoppers: their ecology and management. Chapman and Hall, New York.

Cronin, J. T., and D. R. Strong. 1999. Dispersal-dependent oviposition and the aggregation of parasitism. Am. Nat. 154: 23-36.

Cronin, J. T., K. J. Haynes, and F. Dillemuth. 2004. Spider effects on planthopper mortality, dispersal and spatial population dynamics. Ecology 85: 2134-2143.

Daehler, C. C., and D. R. Strong. 1995. Impact of high herbivore densities on introduced smooth cordgrass, Spartina alterniflora, invading San Francisco Bay, California. Estuaries 18: 409-417.

Daehler, C. C., and D. R. Strong. 1997. Reduced herbivore resistance in introduced smooth cordgrass (Spartina alterniflora) after a century of herbivore-free growth. Oecologia (Berl.) 110: 99-108.

Denno, R. F. 1977. Comparison of the assemblages of sapfeeding insects (Homoptera: Hemiptera) inhabiting two structurally different salt marsh grasses in the genus Spartina. Environ. Entomol. 6: 359-372.

Denno, R. F. 1983. Tracking variable host plants in space and time, pp. 291-341. In R. F. Denno and M. S. McClure [eds. ], Variable plants and herbivores in natural and managed systems. Academic, New York.

Denno, R. F., and H. Dingle. 1981. Considerations for the development of a more general life history theory, pp. 1-6. In R. F. Denno and H. Dingle [eds.], Insect life history patterns: habitat and geographic variation. Springer, New York.

Denno, R. F., L. W. Douglass, and D. Jacobs. 1986. Effects of crowding and host plant nutrition on a wing-dimorphic planthopper. Ecology 67: 116-123.

Denno, R. F., and E. E. Grissell. 1979. The adaptiveness of wing dimorphism in the salt marsh-inhabiting planthopper, Prokelisia marginata (Homoptera: Delphacidae). Ecology 60: 221-236.

Denno, R.F., and E. S. McCloud. 1985. Predicting fecundity from body size in the planthopper, Prokelisia marginata (Homoptera: Delphacidae). Environ. Entomol. 14: $846-$ 849.

Denno, R. F., and G. K. Roderick. 1992. Density-related dispersal in planthoppers: effects of interspecific crowding. Ecology 73: 1323-1334. 
Denno, R. F., M. E. Schauff, S. W. Wilson, and K. L. Olmstead. 1987. Practical diagnosis and natural history of two sibling salt marsh-inhabiting planthoppers in the genus Prokelisia (Homoptera: Delphacidae). Proc. Entomol. Soc. Wash. 89: 687-700.

Denno, R. F., K. L. Olmstead, and E. S. McCloud. 1989. Reproductive cost of flight capability: a comparison of life history traits in wing dimorphic planthoppers. Ecol. Entomol. 14: 31-44.

Denno, R. F., G. C. Roderick, K. L. Olmstead, and H. G. Dobel. 1991. Density-related migration in planthoppers (Homoptera: Delphacidae): the role of habitat persistence. Am. Nat. 138: 1513-1541.

Denno, R. F., G. K. Roderick, M. A. Peterson, A. F. Huberty, H. G. Dobel, M. D. Eubanks, J. E. Losey, and G. A. Langellotto. 1996. Habitat persistence underlies intraspecific variation in the dispersal strategies of planthoppers. Ecol. Monogr. 66: 389-408.

Denno, R. F., M. A. Peterson, C. Gratton, J. A. Cheng, G. A. Langellotto, A. F. Huberty, and D. L. Finke. 2000. Feeding-induced changes in plant quality mediate interspecific competition between sap-feeding herbivores. Ecology 81: 1814-1827.

Denno, R. F., C. Gratton, M. A. Peterson, G. A. Langellotto, D. L. Finke, and A. F. Huberty. 2002. Bottom-up forces mediate natural-enemy impact in a phytophagous insect community. Ecology 83: 1443-1458.

Döbel, H. G., and R. F. Denno. 1994. Predator-planthopper interactions, pp. 325-399. In R. F. Denno and T. J. Perfect [eds.], Planthoppers: their ecology and management. Chapman \& Hall, New York.

English-Loeb, G., M. Rhainds, T. Martinson, and T. Ugine. 2003. Influence of flowering cover crops on Anagrus parasitoids (Hymenoptera : Mymaridae) and Erythroneura leafhoppers (Homoptera: Cicadellidae) in New York vineyards. Agric. For. Entomol. 5: 173-181.

Fagan, W. F., and R. F. Denno. 2004. Stoichiometry of actual vs. potential predator-prey interactions: insights into nitrogen limitation for arthropod predators. Ecol. Lett. 7: $876-883$

Ferrenberg, S. M., and R. F. Denno. 2003. Competition as a factor underlying the abundance of an uncommon phytophagous insect, the salt-marsh planthopper Delphacodes penedetecta. Ecol. Entomol. 28: 58-66.

Finke, D. L., and R. F. Denno. 2003. Intra-guild predation relaxes natural enemy impacts on herbivore populations. Ecol. Entomol. 28: 67-73.

Fowler, S. V., M. F. Claridge, J. C. Morgan, I.D.R. Peries, and L. Nugaliyadde. 1991. Egg mortality of the brown planthopper, Nilaparvata lugens (Homoptera, Delphacidae) and green leafhoppers, Nephotettix spp. (Homoptera Cicadellidae), on rice in Sri Lanka. Bull. Entomol. Res. 81: 161-167.

Garcia-Rossi, D., N. Rank, and D. R. Strong. 2003. Potential for self-defeating biological control? Variation in herbivore vulnerability among invasive Spartina genotypes. Ecol. Appl. 13: 1640-1649.

Gould, F. W. 1968. Grass systematics. McGraw-Hill, New York.

Gratton, C., and R. F. Denno. 2003. Seasonal shift from bottom-up to top-down impact in phytophagous insect populations. Oecologia (Berl.) 134: 487-495.

Hamilton, K.G.A. 2002. Homoptera (Insecta) in Pacific Northwest grasslands, part 1. Description of new taxa and new syonymies in leafhoppers and planthoppers (Cicadellidae and Delphacidae). J. Entomol. Soc. Br. Columbia 99: 3-31.
Haynes, K. J., and J. T. Cronin. 2003. Matrix composition affects the spatial ecology of a prairie planthopper. Ecology 84: 2856-2866.

Haynes, K. J., and J. T. Cronin. 2006. Interpatch movement and edge effects: the role of behavioral responses to the landscape matrix. Oikos 113: 43-54.

Heady, S. E., and R. F. Denno. 1991. Reproductive isolation in Prokelisia planthoppers (Homoptera: Delphacidae) acoustic differentiation and hybridization failure. J. Insect Behav. 4: 367-390.

Heady, S. E., and S. W. Wilson. 1990. The planthopper genus Prokelisia (Homoptera: Delphacidae): morphology of female genitalia and copulatory behavior. J. Kans. Entomol. Soc. 63: 267-278.

Hendrickson, G. O. 1930. Studies on the insect fauna of Iowa prairies. Iowa State Coll. J. Sci. 4: 49-179.

Holder, M. W., and S. W. Wilson. 1992. Life history and descriptions of the immature stages of the planthopper Prokelisia crocea (Van Duzee) (Homoptera: Delphacidae). J. NY Entomol. Soc. 100: 491- 497.

Holt, R. D. 1977. Predation, apparent competition and the structure of prey communities. Theor. Popul. Biol. 12: 197-229.

Holt, R. D., and J. H. Lawton. 1993. Apparent competition and enemy-free space in insect host-parasitoid communities. Am. Nat. 142: 623-645.

Holt, R. D., and J. H. Lawton. 1994. The ecological consequences of shared natural enemies. Annu. Rev. Ecol. Syst. 25: 495-520.

Huberty, A. F., and R. F. Denno. 2006. Trade-off in investment between dispersal and ingestion capability in phytophagous insects and its ecological implications. Oecologia (Berl.) 148: 226-234.

Kiritani, K. 1979. Pest management in rice. Annu. Rev. Entomol. 24: 279-312.

Liljesthrom, G. G., and E. G. Virla. 2004. Density-dependent parasitism of Delphacodes kuscheli eggs by Anagrus flaveolus: influence of egg patchiness and density. Biocontrol Sci. Technol. 14: 107-115.

March, G. J., J. A. Ornaghi, J. E. Beviacqua, J. Giuggia, A Rago, and S. L. Lenardon. 2002. Systemic insecticides for control of Delphacodes kuscheli and the Mal de Rio Cuarto virus on maize. Int. J. Pest Manag. 48: 127-132.

Metcalfe, J. R. 1972. An analysis of the population dynamics of the Jamaican sugarcane pest Saccharosydne saccharivora (Westw.) (Hom., Delphacidae). Bull. Entomol. Res. 62: 73-85.

Meyerdirk, D. E., and M. S. Moratorio. 1987. Biology of Anagrus giraulti (Hymenoptera: Mymaridae), an egg parasitoid of the beet leafhopper, Circulifer tenellus (Homoptera: Cicadellidae). Ann. Entomol. Soc. Am. 80: 272277.

Miller, A., and S. W. Wilson. 1999. The planthopper genus Prokelisia (Homoptera: Delphacidae): exoskeletal morphology of the tymbals. Reichenbachia 33: 37-42.

Olmstead, K. L., R. F. Denno, T. C. Morton, and J. T. Romeo. 1997. Influence of Prokelisia planthoppers on amino acid composition and growth of Spartina alterniflora. J. Chem. Ecol. 23: 303-321.

Ôtake, A. 1970. Studies on the egg parasites of the smaller brown planthopper, Laodelphax striatellus (Fallen) (Hemiptera: Delphacidae). IV. Seasonal trends in parasitic and dispersal activities, with special reference to Anagrus nr. Alaveolus Waterhouse (Hymenoptera: Mymaridae). Appl. Entomol. Zool. 5: 95-104.

Pyke, D. A., and J. N. Thompson. 1986. Statistical analysis of survival and removal rate experiments. Ecology 67: 240 245. 
Reeve, J. D., J. T. Cronin, and D. R. Strong. 1994. Parasitism and generation cycles in a salt-marsh planthopper. J. Anim. Ecol. 63: 912-920.

Roff, D. A. 1984. The cost of being able to fly: a study of wing polymorphism in two species of crickets. Oecologia (Berl.) 63: 30-37.

Roff, D. 1986. The evolution of wing dimorphism in insects. Evolution 40: 1009-1020.

Roff, D. A. 1990. The evolution of flightlessness in insects. Ecol. Monogr. 60: 389-421.

Sculthorpe, C. C. 1967. The biology of aquatic vascular plants. Edward Arnold Ltd., London, United Kingdom.

Settle, W. H., and L. T. Wilson. 1990. Invasion by the variegated leafhopper and biotic interactions: parasitism, competition, and apparent competition. Ecology 71: 1461-1470

Sokal, R. R., and F. J. Rohlf. 1995. Biometry, 3rd ed. W. H. Freeman and Co., New York.

Smith, A. L. 1973. Life cycle of the marsh grass, Scolochloa festucacea. Can. J. Bot. 51: 1661-1668.

Stiling, P. D., and D. R. Strong. 1982. Parasites of the plant hopper, Prokelisia marginata (Homoptera: Delphacidae). Fla. Entomol. 65: 191-192.

Stiling, P. D., A. E. Throckmorton, J. Silvanima, and D. R. Strong. 1991. Biology of and rates of parasitism by nymphal and adult parasites of the saltmarsh-inhabiting planthoppers Prokelisia marginata and P. dolus. Fla. Entomol. 74: 81-87.

Strong, D. R. 1989. Density independence in space and inconsistent temporal relationships for host mortality caused by a fairyfly parasitoid. J. Anim. Ecol. 57: 10651076.

Tallamy, D. W., and R. F. Denno. 1979. Responses of sap-feeding insects (Homoptera: Hemiptera) to simplification of host-plant structure. Environ. Entomol. 8: 1021-1028.
Teulon, D. A., and D. R. Penman. 1986. Temporal distribution of Froggatt's apple leafhopper (Typhlocyba froggatti Baker) and the parasite Anagrus armatus (Ashmead) in an abandoned orchard. N Z. J. Zool. 13: 93-100.

Triapitsyn, S. V. 1997. The genus Anagrus (Hymenoptera: Mymaridae) in America south of the United States: a review. Ceiba 38: 1-12.

van der Valk, A. [ed.] 1989. Northern prairie wetlands. Iowa State University Press, Ames, IA.

Wilson, M. R., and M. F. Claridge. 1985. The leafhopper and planthopper faunas of rice fields, pp. 381-404. In L. R. Nault and J. G. Rodriguez [eds.], The leafhoppers and planthoppers. Wiley, New York.

Wilson, S. W. 1982. The planthopper genus Prokelisia in the United States (Homoptera: Fulgoroidea: Delphacidae). J. Kans. Entomol. Soc. 55: 532-546.

Wilson, S. W. 2005. Keys to the families of Fulgoromorpha with emphasis on planthoppers of potential economic importance in the southeastern United States (Hemiptera: Auchenorrhyncha). Fla. Entomol. 88: 464-481.

Wilson, S. W., J. L. Smith, and P. D. Calvert. 1993. Planthoppers of a Missouri tall-grass prairie (Homoptera: Fulgoroidea). J. Kans. Entomol. Soc. 66: 75-80.

Wilson, S. W., R. F. Denno, C. Mitter, and M. R. Wilson. 1994. Evolutionary patterns of host plant use by delphacid planthoppers and their relatives, pp. 7-113. In R. F. Denno and T. J. Perfect [eds.], Planthoppers: their ecology and management. Chapman \& Hall, New York.

Zera, A. J. 1984. Differences in survivorship, development rate and fertility between the long-winged and wingless morphs of the waterstrider, Limnoporus canaliculatus. Evolution 38: 1023-1032.

Received 1 February 2007; accepted 18 May 2007. 